\title{
The Dialectics of Distance and Nearness in Philosophies of G. W. Fr. Hegel and L. Feuerbach
}

\author{
LINA VIDAUSKYTE் \\ Vilnius University, 3 Universiteto Street, 01513 Vilnius \\ Email: lina.vidauskyte@fsf.vu.It
}

\begin{abstract}
Using the method of $\mathrm{H}$. Blumenberg (metaphorology) the article focuses on 'a dialectics of distance and nearness' in philosophy and everyday life of G. Fr. Hegel and L. Feuerbach (let us say - another two examples of the biography of 'distance' and 'nearness') and here lies the novelty of the article. These metaphors 'distance' and "nearness' are not just a simple decoration of philosophical language, but rather they are indicators of the phenomenological approach to the world. Blumenberg in his work Das Lachen der Thrakerin. Eine Urgeschichte der Theorie analysed the reception of the old story about Thales and Thracian women in the philosophical tradition. The story metaphorically shows the relationship between invisible proto-theory and practical wisdom. It also projects a very significant feature of theory - the exotic behaviour of the observer (absentmindedness). The laughter of practical wisdom means the disappearance of distance and the emergence of everyday importance (nearness). Unfortunately, Blumenberg's methodological approach is not developed further by other philosophers.
\end{abstract}

Keywords: distance, nearness, theory, practice, commonness, absentmindedness, astronomy, philosophy

\section{THE COLLISION OF THEORY AND PRACTICE}

$\mathrm{H}$. Blumenberg is a well-known author of remarkable studies such as The Legitimacy of the Modern Age (1966), The Genesis of the Copernican World (1975) and Work on Myth (1979). Early Blumenberg was highly engaged in the history and philosophy of science and regarding it, we can place the above-mentioned works under the title 'historical epistemology of metaphor and biographies of scientific metaphors'. His methodological approaches are not developed and used today (unfortunately, there is no place to discuss the reason why Blumenberg's method is so difficult to use). Nevertheless, this essay aims at applying Blumenberg's approach in a biography of metaphors on two particular 'cases' - Hegel and Feuerbach. The biography of metaphors, or metaphorology, is methodologically related to Blumenberg's project of anecdotes, where exemplarity (the row of various similar examples compose the philosophical argument) plays a major role (Flemming 2011). Anecdotes about philosophers thus signal anthropological questions about the possibilities of human experience and here we can find 
an influence of L. Landgrebe. Landgrebe's notion of Being-in-the-World includes passive states like sleep, distractedness from the activity and 'makes' us passive participants and expresses 'unconscious' motivation (as we will see later, that is why exotic behaviour, viz. absentmindedness, appears as a significant feature of a theoretician-philosopher). Considering that, one can also include important anthropological movements, which indicate the development of human curiosity - the movement of the sight from the starry heaven (Thales) to the everyday life of the Earth (Thracian woman). An anecdote (or exemplarity) as a method also opens up the possibility to understand Blumenberg's metaphorology by analogy. The anecdote occupies a position in Blumenberg's thought akin to metaphor and goes hand in hand with it (more about metaphor in Blumenberg's philosophy: Bajohr 2015; Hawkins 2017; Vidauskyte 2017). Considering exemplarity as a method, one can say that Blumenberg has done a historical investigation of theory from the ancient Greek proto-philosopher Thales till the German philosopher M. Heidegger: he analyses the reception of an old anecdote in the texts of Plato, Socrates, and the Fathers of the Church, Montaigne, Francis Bacon, Tycho Brahe, L. Feuerbach and Fr. Nietzsche. In this article, this historical way of the theory is understood as the disappearance of spatial distance (astronomy) and the rise of commonness. The main attention is focused on the controversies between Hegel and Feuerbach. Blumenberg ignored Hegel's attitude to an anecdote about Thales, and his decision remains obscure, but, perhaps, it is more interesting to find a parallel of an ancient story in the personal life of Hegel and Feuerbach. Moreover, this article is an attempt to find a few more ways to characterize philosophy as an attitude to reality and its professional mandatories.

For Blumenberg, a proto-history of theory has its origin in ancient astronomy and specific behaviour of an astronomer - he is a distracted observer of the starry heaven. Thus that means that a theory is an exotic behaviour, but at the same time, ' $[t]$ heory is something that no one sees' (Blumenberg 2015: 1). The Greek word théoros means an observer, theoretician. While there is no theory of practical life, nevertheless 'theoretician' of daily life differs from an observer of the starry heaven full of Gods. The spatial distance and inaccessibility of the objects in the starry sky in comparison to the nearness of practical existence's pitfalls represent the theorist's exoticism. The heavens are essentially the object of pure theory because they are at an absolute distance from a man. In the dialectics between 'distance' and 'nearness', we can recognize an old philosophical question. Considering it, some interpretations already spotted the intellectual kinship between Blumenberg and H. Arendt (e.g. Brient 2000) and at this point, it is worth to take a look at Arendt's work The Life of the Mind (1978). According to Arendt, this intersection of theory and practice, distance and nearness is simply the other side of the old metaphysical dichotomy of (true) Being and (mere) Appearance. Astronomy as a proto-theory (the theory is unseen) is the true Being (and it never changes) while mere Appearance is practical wisdom, and in modern times - history, the historical world (Arendt 1978: 24). As we will see later, Hegel's and Feuerbach's philosophical positions are interesting examples of the transition from the theoretical attitude to practical wisdom (even if the starry heaven still controversially appears in their lives and thinking).

\section{HEGEL: WER DENKT ABSTRAKT?}

Probably the first thing that characterizes the perspective of distance is an abstraction, namely what is invisible, and it seems illusionary to everyday consciousness. Hegel in Phenomenology of Spirit convincingly shows that sensory consciousness is the most abstract (Hegel 2004: 58-103), and in another essay Wer denkt abstrakt? (1807) makes a funny description of daily 
consciousness, which is not much less than scientific is thinking in abstractions. In the essay, Hegel criticizes abstract thinking, which (paradox!) is characteristic not of the educated person, but on the contrary - of the uneducated. Hegel writes: 'Who thinks abstractly? The uneducated, not educated. Good society does not think abstractly because it is too easy. After all, it is too lowly (not referring to the external status) - not from an empty affectation of nobility that would place itself above that of which it is not capable, but on account of the inward inferiority of the matter' (Hegel 1966: 113). Hegel analyses a few examples: the first illustration about a murderer, the second about inhabitants of Leipzig, and the third example is from the everyday life of market women; from the maid, Hegel moves to the life of a servant and his master: no servant is worse off than one who works for a man of low class and low income, and he is better off the nobler his master is. The last example is from the life of a soldier in the Prussian army (Hegel 1966: 118). In sum, for Hegel, abstract thinking is a behaviour with someone only as a representative of a class without seeing him as a human. Hegel was not against scientific abstractions - he just displays that abstract, one-sided consciousness as everyday household consciousness. The question is whether the scientific and theoretical thinking can be concrete and if it can, how? Attempts to solve this problem occupy a central position in Hegel's theory (Science of Logic). Hegel's life has common features with the exotic behaviour of Thales, and with the position of a Thracian maidservant. Hegel's biographers have noted a curious feature of the philosopher. His years of childhood and adolescence coincide with an epoch of flourishing German literature when one after the other masterpieces were born: Emilia Galotti, Götz von Berlichingen, The Sorrows of Young Werther, Nathan the Wise, The Robbers. When leaving school, the future philosopher was not yet familiar with these works. The book, from which he cannot retreat, was Johann Hermes' Sophiens Reise von Memel nach Sachsen (1769-1773) - one of the weakest, and one of the most boring products of that time literature. In these five volumes, the images of philistines monotonous daily life are described. What could have been interesting in this book for Hegel? He has something every day and philistine. But let us take a look at his diary:

'Thursday, 14 July. Mr. Professor Abel and Mr. Professor Hopf honored with a visit to our company. We walked with them (!) and listened to their stories about Vienna. Friday, 15 July. I went with Mr. Professor Closs. We read Mendelssohn's Phädon oder über die Unsterblichkeit der Seele. Saturday, 16 July. Today, the city clerk Mr. Kläpfel died, although everyone thought that he was recovering. He left nine children, one of them was appointed in his place eight days before, and another joined the monastery last fall. Tuesday, 18 July. Today, government adviser and secretary secret Mr. Schmidlin died, during the eating from the stroke, when he wanted to take a spoonful.' (Rosenkranz 1844: 436) Hegel's biographer Karl Rosenkranz left an interesting observation about the philosopher: 'He was so brilliant that he could afford to be philistines' (Rosenkranz 1844: 266). Thus, the tension between the desired distance of intelligent man and nearness of everyday life always remained in the philosophy of Hegel. For instance, Hegel carefully wrote down all the household expenses and at the end of the month calculated 'how many more remained in wallet'. According to Rosenkranz, it was the Schwabian habit which was maintained by Fr. Schiller too (Rosenkranz 1844: 265).

But it was once a time when Hegel was a starry gazer and wrote an astronomical treatise. In 1801, Hegel came to Jena with the encouragement of his old friend Schelling, who held the position of an Extraordinary Professor there. Hegel secured a position at the university as a Privatdozent (unsalaried lecturer) after submitting an inaugural dissertation on the orbits of the planets. The title of Hegel's thesis was Dissertatio Philosophica de Orbitis Planetarium. 
It seems that astronomy as a pure theory plays a crucial role in the philosopher's academic and intellectual way (for instance, I. Kant wrote an astronomy treatise too). But in general, according to Blumenberg, the astronomical Copernican revolution is extremely important for the 'self-awareness' of Europe. In the Copernican revolution lies philosophical, religious, scientific and metaphoric meaning. Blumenberg parallels the history of science and history of consciousness: here lies the origin of modernity. These two phenomena are not identical to each other or each other's causes. However, they both come from the preceding processes. But the most important thought for our investigation is this: 'Right with Copernicus, the triumph of the Thracian woman may have been completed; for she had called attention to the Earth's reality with the hidden sense that the real gods are right here' (Blumenberg 2015: 21). In Jena Hegel pronounces that now it is time for the philosophy to gaze into the sky, and to know laws governing the movement of luminaries. At that time a German astronomer Johann Daniel Titius (1729-1796) formulated now the so-called Titius-Bode law, and he used this rule to predict the existence of a celestial object at $2.8 \mathrm{AU}$ from the sun. Titius tried to extract numbers, reflecting the relative distances of the planets from the sun. This empirical law, it would seem, was approved by Fr. W. Herschel in 1781 when he discovered the planet Uranus. Based on the law of Tatius, astronomers surmised that between Mars and Jupiter, there might be further having an unfound planet. The quest began immediately after the discovery of Uranus. For Hegel, all those empirical laws were vain and he suggested to use the Pythagorian regularity and asserted that in the space between the fourth and fifth places, there is no planet. Meanwhile, already in 1801 on 1 January, astronomer Piazza Palermo discovered the first of the smallest planets - Ceres, located between Mars and Jupiter. Later this fact was an excuse for many jokes and even attacks on Hegel's dialectic. So, Hegel went through a similar situation, which once Thales suffered.

Later Hegel in Berlin university turned his gaze away from the sky and Blumenberg carefully analysed this transition. H. Heine during his period of study in Berlin visited Hegel, but Hegel was occupied, just then, with work; so Heine went to the open window and was seized, in the view of the starry heavens, by a romantic disposition toward this expression of divine love and omnipotence. 'Suddenly he, who had entirely forgotten where he was, felt a hand laid upon his shoulder, and at the same time heard the words: "It's not the stars, but what man puts into them that's the real thing!" He turned around and Hegel stood before him. From that moment he knew. Heine concluded that in this man, however impenetrable his doctrine was for Heine, the pulse of the century beat. He never lost the impression of this scene, and whenever he thought of Hegel, he always remembered it' (Blumenberg 1987: 70). Perhaps Heine's testimony let us consider Hegel's life and philosophy as an example of the dialectics of distance and nearness. From this point it is very interesting to look more closely at his university lectures. Susan Buck-Morss analysed Hegel's lectures at Jena University, where she found evidence that Hegel was an attentive reader of Adam Smith's Wealth of Nations and a follower of the Scottish Enlightenment (Buck-Morss 2009: 4). Before K. Marx’s theory, Hegel was the first philosopher who showed attention to someone, who pronounced the importance of economy. 'Hegel's philosophical system may climb to abstract levels $\langle\ldots\rangle$, but his texts are full of the kind of historically concrete detail that theorists with a materialist bent like myself find particularly appealing: pin manufacturing, coffee drinking, poorhouses, men's frockcoats, corkscrews, and candlewick cutters. Even the most abstract terms of Hegel's conceptual vocabulary are derived from everyday experience. In the Jena writings, the central Hegelian term "objectification" (Entäusserung) has as its referent, mundane human labor; "negation" is Hegelian for the desire of consumption; 
and historically created needs, as opposed to natural necessity, are exemplified in the social imitation of fashion' (Buck-Morss 2009: 6-7). It means that Hegel was an acute observer (!) of the rupture in social life that we now call modernity (Buck-Morss 2009: 6). According to BuckMorss, in Jena lectures (1805-06) Hegel for the first time speaks about the relationship between 'master' and 'slave'. From economic themes, he moves to political themes of master and slave and 'the struggle of life and death' (Buck-Morss 2009: 10). Slave struggle and the establishment of a constitutional state allow Hegel to expand his analysis of the colonial economy to world history. Buck-Morss claims that Hegel writes about the real revolutionary events in Haiti. However, despite the present philosophers' arguments that Hegel knew about the events in Haiti, in his text itself, there is not a word about that (Buck-Morss 2009: 16-17). Buck-Morss raises the question: What was an inspiration for the dialectic between master and slave for Hegel? For Buck-Morss, this dialectics is a direct reference to historical reality - the slave revolution in Haiti (Buck-Morss 2009: 48). Hegel's Phenomenology of Spirit was written in Jena, 1805-06, and these are the first years of existence of the Haitian nation. Phenomenology was published in 1807 when Great Britain abolished the slave trade. For Buck-Morss it is clear that Hegel borrowed the dialectics between master and slave from the newspapers (Buck-Morss 2009: 48). Following still authoritative Hegel's biographer Rosenkranz, she says that Hegel treated a reading of the newspaper as a morning prayer. Let us not forget that after Jena Hegel himself worked for a newspaper in Bamberg. Newspaper since the start of modernity can play the role of an indicator of the Thracian maidservant's position. Once W. Benjamin noted that at that time for the newspaper readers 'an attic fire in the Latin Quartier is more important than a revolution in Madrid' (Benjamin 2002: 147). In Hegel's case, geographical nearness plays a crucial role in his professional life of editor in Bamberg's newspaper. The philosopher felt that his vocation is politics, and he could make a direct influence on his readers. Despite a high level of abstraction and idealism in Hegel's philosophy, we can see quite clearly that modern look to everyday life plays a crucial moment in his thinking.

\section{LUDWIG FEUERBACH AND ABSENTMINDEDNESS}

Ludwig Feuerbach started his academic career with a dissertation on Hegel's thought, but later he became very critical to his teacher. It is quite interesting, as Feuerbach did not know the early Hegel's texts and contemporary researchers argue that late Feuerbach is the early Hegel (Wartofsky 1982: 47). Due to unfavourable circumstances forced to live in silence and solitude of rural, Feuerbach fought with idealism. His critique of speculative idealism and his formulation of alternative 'philosophy for the future', humanist materialism, is based on a thoroughgoing sensationalist epistemology. From the Dissertation through the historical works (on Spinoza, Leibniz), the shorter critical reviews, the defense and then the critique of Hegel, Feuerbach becomes successively more skeptical of abstract or speculative philosophy, more intrigued with a nominalist ontology of individuals, more and more concerned with the empirical, the concrete and the human (Wartofsky 1982: 344). For Feuerbach, theology and philosophy are just a kind of anthropology.

According to Blumenberg, '[t]he expression "absentmindedness" (Geistesabwesenheit) has unprecedented meaning in Feuerbach's language. He designates Idealism's exoticism as a way of life: between the risks that Idealism distorts reality and the humor of its involuntary distance from life. The writer is the professional incarnation of this way of life, which Feuerbach describes as "humorous-philosophical" (Blumenberg 2015: 92). That very absentmindedness lands him near the anecdotic configuration between Thales and Thracian maidservant, 
even if Feuerbach chooses, instead of someone tumbling into a well, someone drifting out onto the high sea with risky prospects as a metaphor for what has also been called losingthe-ground-under-one's-feet (Den-Boden-unter-den-Füßen-verlieren) (Blumenberg 2015: 92). Where the loss of reality and realism is supposed to be lamentable, the ground under one's feet is the most common metaphor; if this is meant to describe leaving the lifeworld, or turns into the metaphor for the inconspicuous assurances which compromise the syndrome of life-worldliness - the thematizing of which will be one of philosophy's latest insights. Feuerbach thus prefers to describe his authors' 'absentmindedness' with the unfathomability of the sea rather than that of the well: 'On the high sea of mental productivity, where the idea of infinity is present to the human otherwise sets a firm foot and builds his petty Philistine world' (Feuerbach 1903: I, 31; on the metaphor of 'the high sea', see Blumenberg, 1997: 7-10). Blumenberg metaphorically argues that humans live their lives and build their institutions on dry land. 'Nevertheless, they seek to grasp the movement of their existence above all through a metaphoric of the perilous sea voyage' (Blumenberg 1997: 7). Feuerbach argued that sensory perception does not think abstractly and finally the nearness, the petty philistine world has more respect than the ridiculous abstract thinking of idealism. However, Blumenberg asserts that 'the relationships of far and near that play against each other in the Thales anecdote are still on the conceptual aids by which Feuerbach's realism determines the beginning of philosophy and its distance from this beginning. No longer is what lies in front of the feet and gets overlooked there the epitome of the real, but something more brutish, what is "incorporated": breathing and eating' (Blumenberg 2015: 94). The nearest comes so close that it can only be the farthest in time: the last approach by human wisdom to humanity itself, that 'you are what you eat' (Feuerbach 1911: X, 343). So, nutrition science appears as quasi-ontology.

For Feuerbach, the professional language of speculative idealism was a sign of written language, an attribute of a writer, and he was very concerned with its style. In comparison with Hegel's philosophical system, which climbed to abstract levels and became hardly understandable, Feuerbach was the opposite: all editions of his writings were carefully edited, processed, and he constantly emphasized the discrepancy of spoken and written word. However, a student who heard Hegel's early lectures at Jena claimed that he 'could make absolutely nothing of them, had no idea what was being discussed, duck or geese' (Buck-Morss 2009: 6). According to Warnofsky, 'the humanization and deprofessionalization of his style were, for Feuerbach, a personal expression of his anti-professionalism (i.e. philosophical professionalism or "professorism") and for his sense that the writer and the man had to be in intimate union.' In an early literary effort, little noted (The Writer and the Man, published in 1834), he had written, 'Do you want to recognize and judge the man in the writer? Yes... because the writer reveals his true self, which is at one with his creative spirit, in his writings... it is in these that his true being can be recognized and judged' (Warnofsky 1982: 343). And in his Diary (1834-6, published in 1846 as part of the Fragments towards a Characterization of My Philosophical Curriculum Vitae) Feuerbach added, 'One writes for others, not for oneself. In any case, I can't write for myself alone. What I write must be directly addressed towards another person or to humankind in general. Therefore, I write as clearly and lucidly as possible. I don't want to torment other people with my writings' (Feuerbach 1911: X, 168). A more despairing view of the gap between thinking and writing appears in the Posthumous Aphorisms: 'We always are more and think more than we write. Writing involuntarily fixes the self in a one-sided way. Our otherwise fluent ideas, which are bound up in our living intercourse with others, become static and fixed as soon as they are put on paper. From the written page, one can't 
read back or conclude anything more than what the person is on paper. There is an infinite difference between the paper-person and the real, living person' (Feuerbach 1911: X, 346). Nevertheless, something happened there, which Feuerbach first described towards the end of his life as the ultimate intensification of 'absentmindedness' through an example from his own experience: 'When I once suddenly noticed a majestic meteor while observing the starry sky, I wanted to call the people in the nearby room over to share the pleasure but I could not call out; I was speechless' (Feuerbach 1911: X, 211). In his enthusiasm for astronomy, Feuerbach almost feels caught in the old thought that astronomy has to do with a higher reality, with a more pure reality, with the part of nature closer to thought itself (Blumenberg 2015: 96). There is no doubt that Blumenberg in his analysis of Feuerbach's attitude to professional style and idealism, expressed his preference for astronomy. But in general, Feuerbach's fight with Hegel's idealism shows that modern Thracian woman's attitude won over the former starry gazer's view.

\section{CONCLUSIONS}

The beginning of Western philosophical tradition is closely related to the observation of stars, namely astronomy. At the same time, it is a pure theory that no-one sees, especially for a man who is not initialized in this process. In Antiquity the anecdote about the astronomer-philosopher Thales and Thracian maidservant was born: distracted astronomer felt in the well while observing stars in the heaven, and a Thracian woman, who is the personalization of practical wisdom, laughed at him. According to Blumenberg, it allows reflecting on the relationship between the theory (a distance) and daily nearness.

One of such examples between philosophy and everyday life can be controversial, metaphorical and anecdotical situations of the personal and professional life of Hegel and Feuerbach. Hegel's abstract philosophical language can be treated as opposition to Feuerbach's clear, anti-professorian style. Nevertheless, they both have an unusual relationship with the starry heaven: Hegel started his professional career with astronomical treatise, while Feuerbach, philosopher of a 'digital' clearness of style, finished his professional life with an astonishing silence in the face of the starry heaven. This strange anecdotical dialectic lets us see how the Thracian maid position gradually takes a basic position in the Western philosophical tradition.

Received 5 September 2019

Accepted 24 February 2020

\section{References}

1. Arendt, H. 1978. The Life of the Mind. A Harvest Book-Harcourt, Inc.

2. Bajohr, H. 2015. 'The Unity of the World: Arendt and Blumenberg on the Anthropology of Metaphor', The Germanic Review 90: 40-52.

3. Benjamin, W. 2002. 'The Storyteller. Observations on the Works of Nikolai Leskov', in Selected Writings, Vol. 3. Cambridge: Belknap Press of Harward University Press, 1935-1938.

4. Blumenberg, H. 1987. The Genesis of the Copernican World. Cambridge: The MIT Press.

5. Blumenberg, H. 2015. The Laughter of the Thracian Woman. A Protohistory of Theory. New York: Bloomsbury.

6. Blumenberg, H. 1997. Shipwreck with Spectator: Paradigm of a Metaphor for Existence. Cambridge, MA.

7. Brient, E. 2000. "Hans Blumenberg and Hannah Arendt on the "Unworldly Worldliness" of the Modern Age', Journal of the History of Ideas 61(3): 513-530.

8. Buck-Morss, S. 2009. Hegel, Haiti, and Universal History. University of Pittsburgh Press.

9. Feuerbach, L. 1903-1911. Sämmtliche Werke. Stuttgart: Wigand.

10. Fleming, P. 2011. 'The Perfect Story: Anecdote and Exemplarity in Linnaeus and Blumenberg', Thesis Eleven (SAGE) 104(1): 72-86. 
11. Hawkins, S. 2017. 'Anecdote as Philosophical Intervention: Hans Blumenberg's Figure of the Absentminded Phenomenologist', Monashefte 109( 3): 430-452.

12. Hegel, G. W. F. 1995. Lectures on the Greek History of Philosophy. Greek Philosophy to Plato. Transl. by E. S. Haldane. Lincoln, London: University of Nebraska Press.

13. Hegel, G. W. F. 2004. Phenomenology of Spirit. Transl. by A. V. Miller. Oxford University Press.

14. Hegel: Texts and Commentary. 1966. Ed. W. Kaufmann. NY: Anchor Books.

15. Rosenkranz, K. 1844. Georg Wilhelm Friedrich Hegel's Leben. Supplement zu Hegel's Werken. Berlin: Verlag von Duncker und Humblot.

16. Vidauskyte, L. 2017. 'Metaphor of Existence: Seafaring and Shipwreck', Filosofija. Sociologija 28(1): $11-19$.

17. Wartofsky, M. W. 1982. Feuerbach. Cambridge: Cambridge University Press.

LINA VIDAUSKYTÉ

\title{
Tolumos ir artumos dialektika G. W. Fr. Hegelio ir L. Feuerbacho filosofijose
}

\begin{abstract}
Santrauka
Pasitelkus H. Blumenbergo metodą (metaforologiją) siekiama išryškinti „tolumos“ ir „artumos" dialektiką G. W. Fr. Hegelio ir L. Feuerbacho filosofijose ir kasdieniuose gyvenimuose. H. Blumenbergo metodologinès prieigos nèra plètojamos kitų filosofų, todèl šio straipsnio tematika yra nauja. Galima net teigti, kad G. W. Fr. Hegelio ir L. Feuerbacho filosofijų analizė yra dar vienas pavyzdys "tolumos“ ir „artumos“ metaforų istorijoje. Minètos metaforos nèra paprasčiausios filosofinès kalbos puošmenos, bet fenomenologinio santykio su pasauliu indikatoriai. H. Blumenbergas savo darbe Das Lachen der Thrakerin. Eine Urgeschichte der Theorie analizavo seno anekdoto apie astronomą, filosofą Talị ir tarnaitę trakietę recepciją filosofineje tradicijoje. Šis anekdotas metaforiškai atskleidžia santykị tarp nematomos proto teorijos ir praktinès išminties. Istorija taip pat išryškina reikšmingą teorijos požymi - egzotišką stebėtojo elgseną (nenuovokumas). Praktinès išminties juokas reiškia tolumos išnykimą ir kasdienybės (artumos) svarbumo iškilimą.
\end{abstract}

Raktažodžiai: toluma, artuma, teorija, praktika, kasdienybė, nenuovokumas, astronomija, filosofija 